УДК 004.738

Режим доступу до журналу: http://www.journal.iitta.gov.ua

Малицька Ірина Дмитрівна, старший науковий співробітник Інформаційноаналітичного відділу педагогічних інновацій Інституту інформаційних технологій i засобів навчання НАПН України, м. Київ, e-mail: Irina_Malitskaya@mail.ru

\title{
ФЕНОМЕН ВІРТУАЛЬНИХ ОСВІТНІХ СПІЛЬНОТ У СИСТЕМАХ ОСВІТИ ЗАРУБІЖНИХ КРАЇН: ПІДХОДИ ДО ВИЗНАЧЕННЯ ПОНЯТЬ
}

\begin{abstract}
Анотація
Популярність віртуальних спільнот, які існують і постійно розвиваються в мережі Інтернет спричинила створення віртуальних спільнот освітнього напряму. Їх можливості успішно використовуються у системах освіти зарубіжних країн, в тому числі в навчальному процесі загальної середньої школи.Феномен віртуальних освітніх спільнот $є$ темою дослідження багатьох науковців світу, узгодження термінологічного апарату продовжується і до цього часу. У статті проаналізовано і запропоновано деякі підходи до визначення понять із цієї проблеми, а саме: віртуальних, віртуальних освітніх та віртуальних навчальних спільнот.

Ключові слова: інформаційно-комунікаційні технології, віртуальні освітні спільноти, віртуальні навчальні спільноти, загальна середня школа, зарубіжний досвід.

Актуальність i постановка проблеми. Одним із пріоритетів Стратегії «Свропа 2020», затвердженої у березні 2010 року країнами-членами Європейського Союзу[1], визначено розвиток інформаційно-комунікаційних технологій (ІКТ) як основи цифрової європейської економіки. 3 огляду на цей установчий документ. у системах освіти як країн Свропи, так і в Україні, одним із головних завдань означено підтримку впровадження і використання IКТ на всіх рівнях освіти, особливу увагу приділяючи загальній середній освіті. Така спрямованість обумовлена швидким розвитком й удосконаленням різноманітних електронних пристроїв (комп'ютерів, ноутбуків, планшетів, iPad-iв, смартфонів, iPnone-ів тощо) і у зв'язку з цим високим рівнем мотивованості учнів, особливо загальної середньої школи, щодо їх опанування. Інтегрування інформаційно-комунікаційних технологій у навчальний процес школи включає використання і вміння володіти на належному рівні такими
\end{abstract}


сучасними електронними засобами. Їх уміле використання свідчить про належну ІКТ грамотність як учня, так і вчителя.

Бажання учнів якнайшвидше опанувати електронними пристроями нового покоління, які у геометричній прогресії з'являються й удосконалюються, а також новітніми сервісами мережі Інтернет вдало використовується педагогами зарубіжних країн й України для підвищення рівня якості навчання і відповідності його сучасним вимогам базових освітніх стандартів. Мегапопулярність мережі Інтернет, відкритий доступ до комунікації, великої кількості інформації, а втім, до отримання нових знань значно сприяє і впливає на розвиток та формування нових освітніх технологій, їх використанню у навчальному процесі загальної середньої школи. Популярність серед молоді таких соціальних мереж, як: Connect, Facebook, Faces.com, LiveJournal, Вконтакте, Одноклассники.ru та ін., на базі яких створюються i розвиваються віртуальні спільноти, спонукає педагогів різних країн світу до вивчення цього феному. Заради успішного спілкування в таких осередках необхідним є швидке опанування новітніми IКТ, набуття IКT компетентності. Така мотивованість учнів прискорила створення i використання віртуальних освітніх сnільнот (ВОС) у системах освіти країн зарубіжжя, а також в Україні, що у свою чергу спонукає всіх учасників навчально-виховного процесу (учнів, учителів, адміністраторів, батьків) до набуття й удосконалення IКТ грамотності.

Аналіз останніх досліджень і публікацій. Феномен ВОС вивчають науковці багатьох країн світу: Говард Рейнгольд, Карен Свон, Пітер Ші (США); Етьєн Венгер, Сабіна Сойферт (Швейцарія); Бондаренко С. В., Моісеєва М. В., Патаракін Є. Д., Полат Є. С., Хуторський А. В., Чураєва Н. С. (Росія); Биков В. Ю., Жалдак М. І., Задорожна Н. Т., Литвинова С. Г., Кухаренко В. М. (Україна) та інші.

Метою статmі є висвітлити актуальність використання можливостей віртуальних спільнот у системах освіти зарубіжних країн і в Україні, проаналізувати існуючи терміни й поняття щодо віртуальних спільнот освітнього напряму.

Виклад основного матеріалу. Узгодження термінології щодо віртуальних спільнот так само, як і віртуальних освітніх спільнот продовжується до цього часу. Саме словосполучення віртуальні спільноти має відношення як до соціології (спільноти), так і до технологій (віртуальні). 
Віртуальні спільноти фактично існують з 1979 року з моменту створення в Інтернеті Ньюзгрупс (Usenet newsgroups). Перш за все цей термін визначали соціологи, спираючись на основне ключове слово - спільнота. У перекладі 3 англійської мови слово спільнота community визначається у словниках Вебстера (Webster's new world dictionary of the American language) [2] й Оксфордському короткому тлумачному словнику (The Concise Oxford Dictionary) [3] як: 1) «... люди, які проживають в одному місці - регіоні або країні за однаковими правилами $\mathrm{i}$ законами», 2) «...група людей, які проживають разом, мають спільні інтереси, роботу, діяльність і т. д.», 3) «спільна участь у якомусь процесі або володіння чимось». Ожегов С. І. надає схоже тлумачення: «спільнота — об'єднання людей, які мають спільні цілі» [4].

Термін онлайн (online або on-line) і віртуальний (virtual) в Інтернет словниках і за своєю суттю поняття найчастіше ототожнюються, хоча мають деякі відмінності. Якщо слово онлайн ми сприймаємо як «процес або операцію, які проходять в режимі реального часу» [5] або “різноманітну діяльність, яку користувач може здійснювати через Інтернет, наприклад: онлайн розмови, ігри, покупки, пошук та інше» [6], термін віртуальний з позиції Інтернету визначений як: «штучне відтворення реальної речі, що означає майже «теж саме». Цей термін ставиться перед багатьма іншими Інтернет термінами і так вказує на технологію моделювання, яка дозволяє вам спілкуватися й обмінюватися досвідом, не зважаючи на кордони між країнами і без необхідності, фізично знаходитися будь-де. Інтернет сам собою розглядається як віртуальний світ, але більшість користувачів вважає за краще термін онлайн” [6].

Об’єднуючи два основоположних слова: сnільнота і віртуальна відомий американський письменник, дослідник віртуальних спільнот Говард Рейнгольд ще у 1980 році одним з перших визначив цю дефініцію (яку найчастіше цитують до цього часу) як: «віртуальні спільноти - це соціальні накопичення людей, які $\epsilon$ користувачами мережі i достатньо довгий період часу продовжують публічні обговорення якоїсь проблеми, виражаючи своє особисте відношення до неї, формуючи свою особисту мережу взаємовідносин у кіберпросторі» [7]. Використане Говардом Рейнольдом поняття «кіберпростору» (cyberspace) не має стандартної дефініції. Подекуди його ототожнюють з поняттям віртуальної реальності, але більше 
відносять до цифрового світу, фізичної інфраструктури, яка створена комп’ютерними мережами, зокрема, Інтернет [6].

Так само частіше за все ототожнюються поняття он-лайн спільнот (online community) i віртуальних спільнот (virtual community) і визначаються як: «онлайн (віртуальна) спільнота або група людей (зі спільними інтересами), які спілкуються в Мережі, BBS, (відео) конференції або якимсь іншим електронним способом» [8].

Заслуговує уваги і таке визначення: «віртуальне співтовариство є група осіб, які, знаходячись у стані взаємозалежності один від одного, координують i погоджують свою спільну діяльність за допомогою Інтернет-технологій» [9]. Усі терміни визначають дві головні характеристики віртуальних спільнот - спільну взаємодію й інформаційно-комунікаційні технології. Визнаючи, що користувач, спілкуючись у віртуальній спільноті, отримує і засвоює відповідну інформацію, має можливість удосконалити свої ІКТ-навички, логічним продовженням розвитку віртуальних спільнот у кіберпросторі стало формування віртуальних спільнот освітнього напряму.

Поняття віртуальних освітніх спільнот (ВОС), спрямованих на освітні цілі, в англомовному контексті визначають як: educational virtual communities (освітні віртуальні спільноти), virtual communities of practice (віртуальні спільноти практики) та ін. У країнах пострадянського простору і в Україні найбільш вживається термін віртуальні освітні спільноти, мережні педагогічні спільноти або віртуальні мережні спільноти освітнього напряму.

Термін віртуальних спільнот, які спрямовані на навчання i визначені як спільноти практики (communities of practice) або віртуальні спільноти практики (virtual communities of practice) був введений всесвітньовідомим швейцарським дослідником визнаним лідером із вивчення і дослідження електронних cniльнот практики (electronic communities of practice) Етьєном Венгером, під яким він розуміє «групи людей, які розподіляють взаємний інтерес до чогось, чим вони займаються та навчаються, як це зробити краще на основі їх постійного, регулярного взаємного спілкування» [10].

Виходячи з того, що всі існуючи ВОС створені на базі Інтернет, усі вони мають мережну структуру. Російський учений, дослідник віртуальних спільнот Бондаренко С. В. надає таке визначення ВОС: «віртуальними мережними спільнотами освітньої 
спрямованості (educational virtual communities) називаються об'єднання, що мають упорядковану структуру користувачів комп'ютерних мереж, які здійснюють комунікацію в освітніх цілях і мають при цьому стійкі соціальні ролі, а також дотримуються відповідних норм поведінки у віртуальному просторі» [11].

Дуже важливим, на нашу думку, у визначенні такого терміну як віртуальна освітня спільнота, необхідно ураховувати не тільки цільове призначення, технічне оснащення, програмне забезпечення, але й норми поведінки, загальноприйняті етичні вимоги, мережний етикет під час спілкування між учасниками спільноти.

Проаналізувавши існуючу термінологію, ми надаємо таке формулювання віртуальних освітніх спільнот, як: «віртуальними освітніми спільнотами називаються групи людей, учасників освітнього процесу (політики 3 освіти, освітяни, адміністратори, учителі, учні тощо), яких об'єднують спільні інтереси, ініціативи, взаємодії, пов'язані з освітніми цілями й освітнім контентом, які постійно і тривалий час спілкуються, використовуючи інформаційно-комунікаційні технології, загальні сервіси і програмне забезпечення, дотримуючись належних норм поведінки у віртуальному просторі».

Існування й інтеграція віртуальних освітніх спільнот (BОC) у системах освіти країн зарубіжжя і в Україні, поступово створює єдиний освітній простір, як у локальному, так і в глобальному вимірі. Задіяні в освітньому процесі, вони мають багато характеристик i форм. ВОС можуть відрізнятися за своїми цілями i використовувати синхронні або асинхронні комунікативні методи, вони можуть знаходити своє місце у різних контекстах, включаючи традиційні класні кімнати, онлайн курси або дистанційні освітні програми.

ВОС можна класифікувати за різними критеріями, наприклад: кількістю учасників, спільною діяльністю (учителі, учні, адміністратори, батьки), рівнями системи освіти (початкова, середня, вища школа, професійна освіта та підготовка тощо), відповідно до визначених спільних проблем і тематик (учителі, учителі науковці, учні, учителі - учні, учителі - батьки тощо).

3 усього різноманіття ВОС зупинимось на віртуальних навчальних спільнотах (BHC) (virtual learning communities), які, на наш погляд, є більш звуженим поняттям відносно ВОС. Вони більш спрямовані на навчальний процес і його вдосконалення завдяки IКТ. Використання ВНС швидко поширюється в загальній середній школі 
зарубіжних країн, створюючи відповідне віртуальне навчальне середовище. Визначення термінології ВНС також знаходиться на стадії дискусій.

В англомовному контексті такі спільноти називають як e-learning communities (електронні навчальні спільноти), virtual learning communities (віртуальні навчальні спільноти) тощо, поєднуючи їх з віртуальним навчальним середовищем (virtual learning environment). Віртуальні навчальні спільноти розглядаються як спільноти, створенні задля навчання, сформовані не за місцем проживання всіх ії учасників, але об’єднані спільною ідеєю, проблемою, метою пов’язаною з процесом навчання. Так само як і поняття ВОС в англійському контексті ототожнюються терміни онлайн навчальні спільноти (online learning communities) і віртуальні навчальні спільноти (virtual learning communities) визначені як: «спільноти, в яких панує: атмосфера навчання, контекст, який забезпечує належну систему підтримки, завдяки якій задіяні навчальні процеси здійснюються через діалог і колаборативне формування знання, набуваючи, генеруючи, аналізуючи і структуруючи інформацію” [12].

Крім цього, Литвиновою С. Г. відокремлюється поняття віртуальної предметної спільноти, яку вона визначає як: «об'єднання вчителів-предметників, яке виростає з мережі, має спільні інтереси, прагнення та цілі, активно спілкується між собою як на професійні, так і на непрофесійні теми» [13].

Існуючи у віртуальному просторі, спільноти освітнього напряму можуть бути цільово зорієнотованими за своїм призначенням (тільки ВОС або тільки ВНС), а також поєднувати в собі обидва контексти, характерні як для ВОС, так і для ВНС.

Наведемо декілька прикладів найбільш розвинутих і діючих віртуальних спільнот освітнього напряму, які задіяні в системах освіти країн зарубіжжя.

Як приклад віртуальної освітньої спільноти, міжнародного значення, яка відіграє велику роль у підтримці, створенні та використанні ресурсів віртуальних освітніх спільнот у навчальному процесі загальної середньої освіти є SITE [14]. 


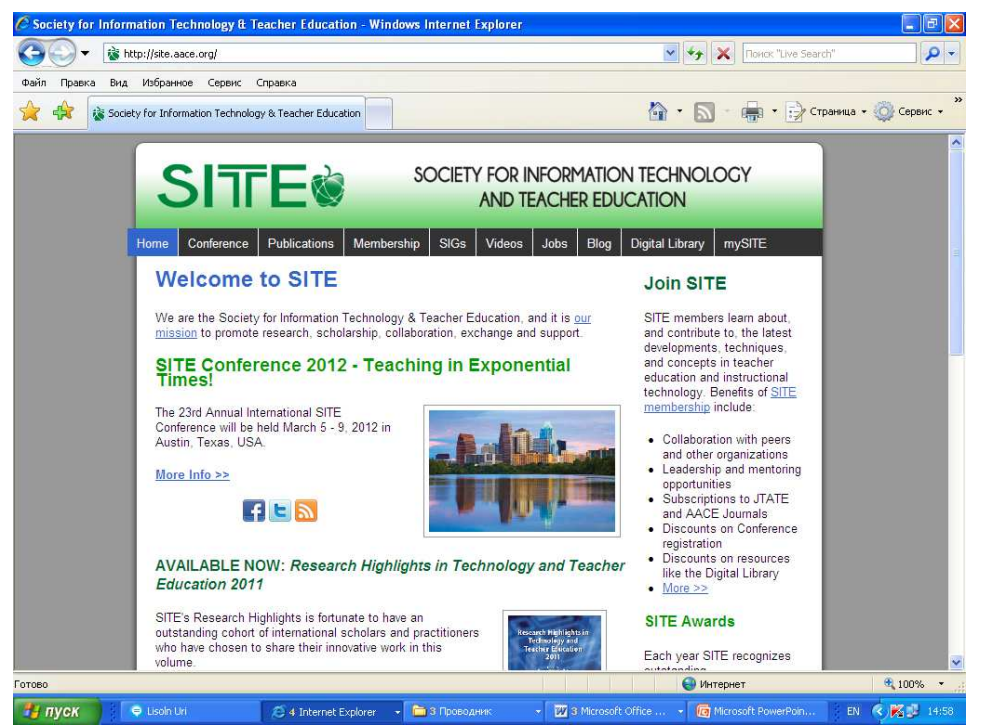

Puc. 1. SITE (The Society for Information Technology and Teacher Education) Суспільство для інформачійних технологій та освіти вчителів http://site.aace.org/

SITE - міжнародна освітянська, професійна організація, у той же час віртуальна освітня спільнота, заснована з метою підвищення рівня знання, теорії, якості навчання та викладання на всіх рівнях освіти, використовуючи інформаційні технології. До ії складу входять освітяни, адміністратори, політики з освіти, учителі 3 різних дисциплін, дослідники, різні міжнародні та освітянські організації. Основна діяльність спрямована на акумулювання й розповсюдження позитивного досвіду, знань з використання IКТ в процесі роботи, навчання і викладання, охоплюючи всі ланки системи освіти. SITE як віртуальна освітня спільнота має можливість широкого обговорення проблем 3 IKT в освіті, що уможливлюється завдяки

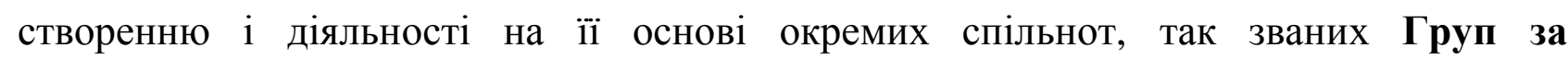
спеціальними інтересами (Special Interest Groups (SIGs)), які об'єднують представників систем освіти з усього світу за означеними проблематиками відповідно до двох основних напрямів: Інформаційні технології і Навчання учителів.

У європейському освітньому просторі ВОС найчастіше формуються в рамках проведення міжнародних освітніх проектів, які підтримуються на державному рівні. Проектна діяльність мотивує учнів і вчителів не тільки розвивати свої комунікативні навички, креативні підходи до виконання будь-яких завдань, критичне мислення, але й опановувати відповідними IКТ-навичками, набувати IКТ компетентність. Можна зазначити декілька найбільш популярних міжнародних проектів, що проводяться на основі Європейської шкільної мережі (European Schoolnet (EUN)), у рамках яких створюються віртуальні освітні спільноти. 
Одним із таких проектів $є$ iTEC (Innovative Technologies for an Engaging Classroom) Інноваційні технології для удосконалення класної кімнати.

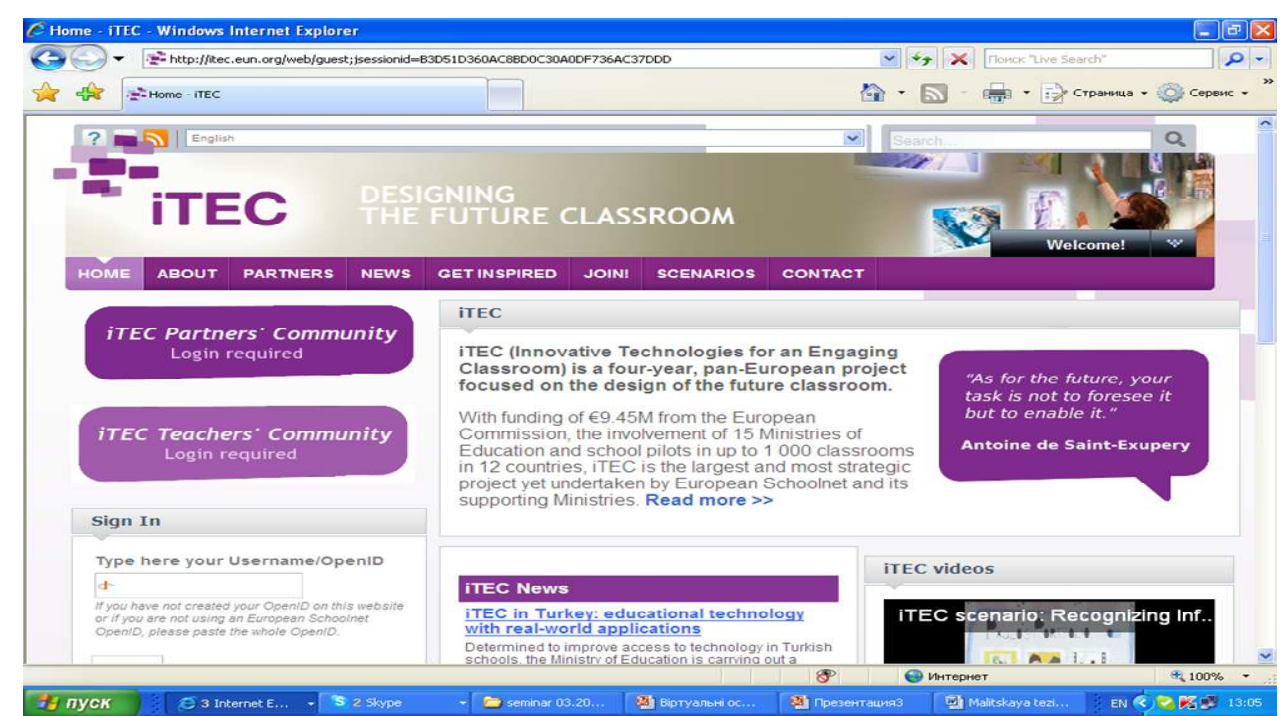

Puc. 2. iTEC (Innovative Technologies for an Engaging Classroom)

Інноваційні технології для удосконалення класної кімнати http://itec.eun.org/web/guest

До проекту іTEC залучено 27 партнерів із 18 країн Свропи. Основною метою визначено формування віртуального освітнього середовища, спрямованого на спільну співпрацю, інтерактивну взаємодію політиків 3 освіти, науковців, розробників технологій, учителів-новаторів, які створюють найбільш вдалі плани і сценарії проведення уроків з використанням ІКТ. Запропоновані матеріали відповідають сучасним вимогам і потребам як учнів, так і вчителів, а також заохочують їх до опанування й удосконалення володіння ІКТ. Усі розробки проходять апробацію в школах європейських країн і оцінюються експертами й учасниками віртуальної спільноти [15].

Прикладом віртуальної спільноти освітнього напряму, спрямованої як на освітянські потреби взагалі, так і на навчальний процес 3 вивчення мов, є віртуальна освітня спільнота іTILT (Interactive Technologies in Language Teaching Інтерактивні технології у навчанні мов). 


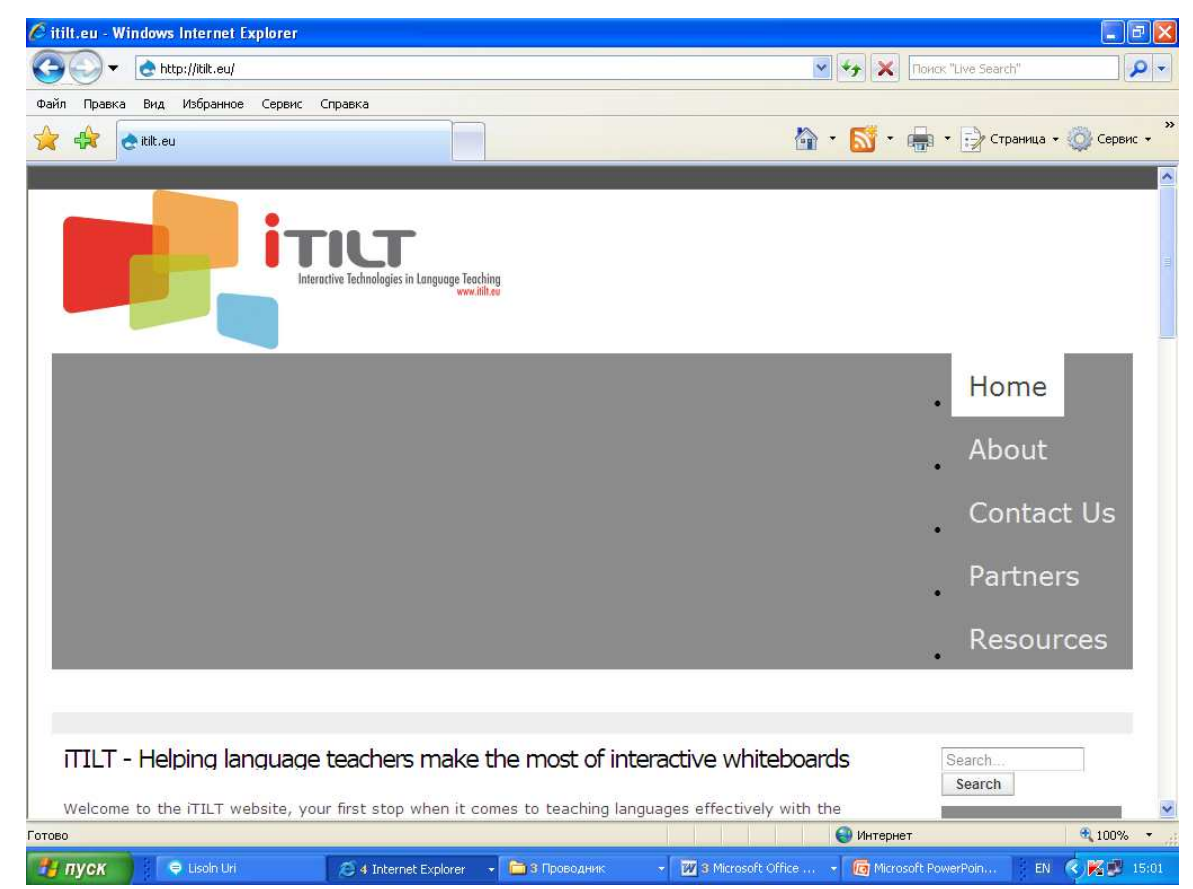

Puc. 3. iTILT - Interactive Technologies in Language Teaching Інтерактивні технології у навчанні мов http://itilt.eu/

До віртуальної освітньої спільноти іTILT залучено вчителів з викладання мов усіх рівнів загальної середньої і післядипломної освіти, спеціалістів із вивчення технологій, спеціалістів, які мають право на прийняття рішень у сфері освіти. Однією 3 основних ідей $\epsilon$ підтримка $\mathrm{i}$ розповсюдження найкращої практики 3 комунікативного методу навчання мов завдяки використанню інтерактивної дошки. На думку європейських освітян, такий підхід допомагає успішній інтеграції новітніх медіа в навчальний процес і відповідає потребам сучасних студентів щодо використання різних методів навчання. У рамках віртуальної освітньої спільноти ITILT створено віртуальну навчальну спільноту, спрямовану на навчання вчителів інтерактивних технологій, а саме використання можливостей інтерактивних дошок під час проведення уроків, обмін досвідом між учителями-практиками, обговорення найбільш вдалих стратегій із подальшою спільною розробкою методичних матеріалів [16].

Віртуальні освітні спільноти найчастіше створюються на базі вже існуючих освітніх мереж, які мають відповідну платформу, таких як: глобальна освітня мережа Xplora, GlobalSchoolNet, Educared, Happychild, European Schoolnet (EUN), Teachers network (Мережа вчителів - Великобританія), Мережа творчих учителів (Росія) «Открытый класс. Сетевые образовательные сообщества», мережа „іEARN” 
(International Education and Resource Network), мережа «Партнерство в навчанні» (Україна) та інші.

Одним iз таких прикладів $є$ Проект eTwinning, який проводиться Європейською шкільною мережею (European Schoolnet (EUN)).

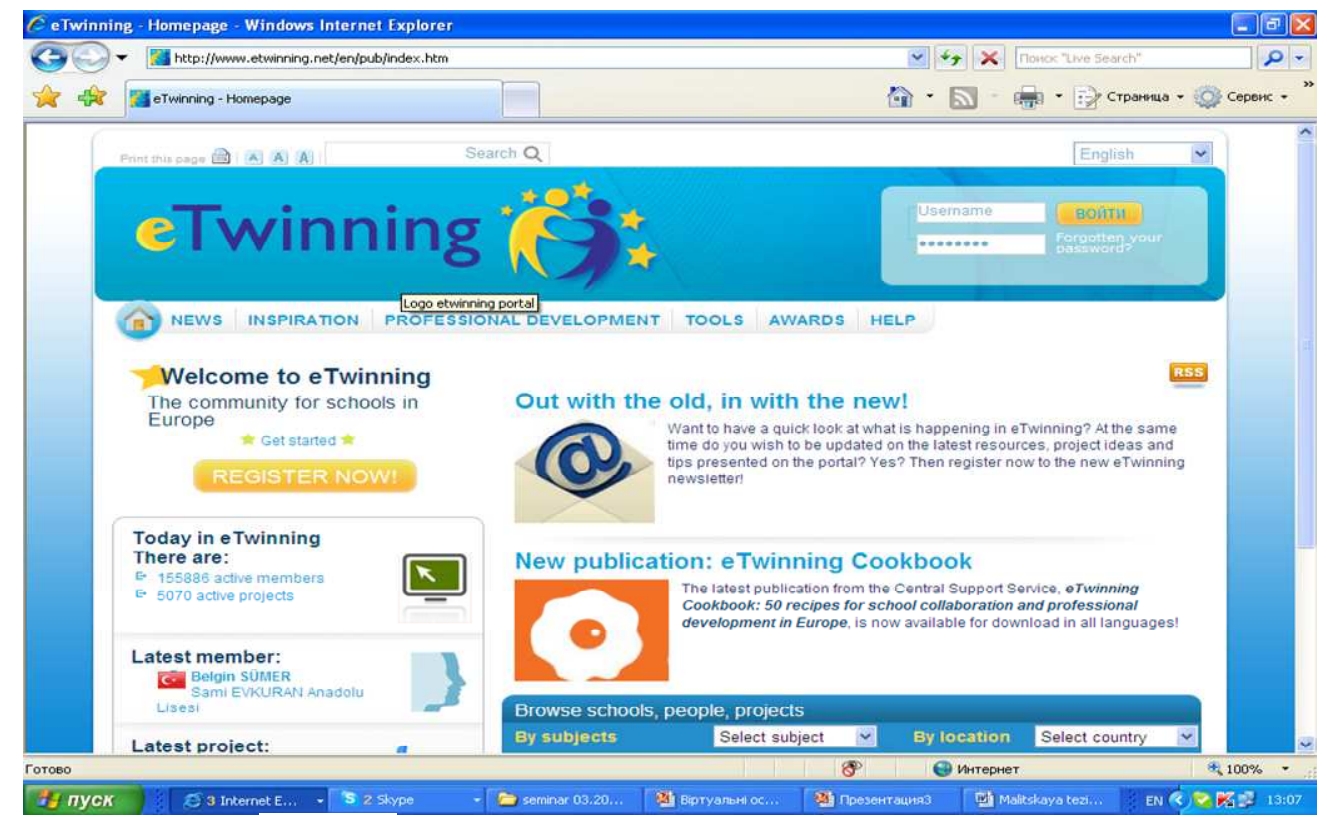

Pис. 4. Міжнародний проект «еTwinning»

http://www.etwinning.net/en/pub/index.htm

Проект eTwinning називають Спільнотою для шкіл в Свропі (The community for schools in Europe) i може бути визначений більш як віртуальна навчальна спільнота. Учителі з різних країн використовують розміщені на сайті он-лайн інструменти, об’єднуються у спільноти, у яких вони навчаються, обмінюються досвідом з використання ІКТ у навчальному процесі, обговорюють і створюють інноваційні методи навчання і викладання в інтерактивному режимі.

Крім спільноти вчителів у рамках шкільних проектів формуються спільноти учнів (як мінімум це дві школи з різних країн), які співпрацюють відповідно до обраної тематики, використовуючи IКТ [17].

Освітня діяльність у віртуальному просторі вимагає від учителів володіння Інтернет сервісами на досить високому рівні, що спонукало до створення віртуальної навчальної спільноти Teach.us (http://www.eun.org/) спрямованої на вивчення сервісів web 2.0. У рамках спільноти співпрацюють експерти і досвідчені вчителі з усієї Європи, які обмінюються досвідом, створюють навчальні матеріали, удосконалюють свої ІКТ навички, що сприяє впровадженню нових підходів до викладання і навчання у класі, а також налагодженню більш тісного зв’ язку зі студентами [18]. 
В Україні у співробітництві Національної академії педагогічних наук України $з$ компанією «Майкрософт Україна» було започатковано освітню мережу «Партнерство в навчанні».

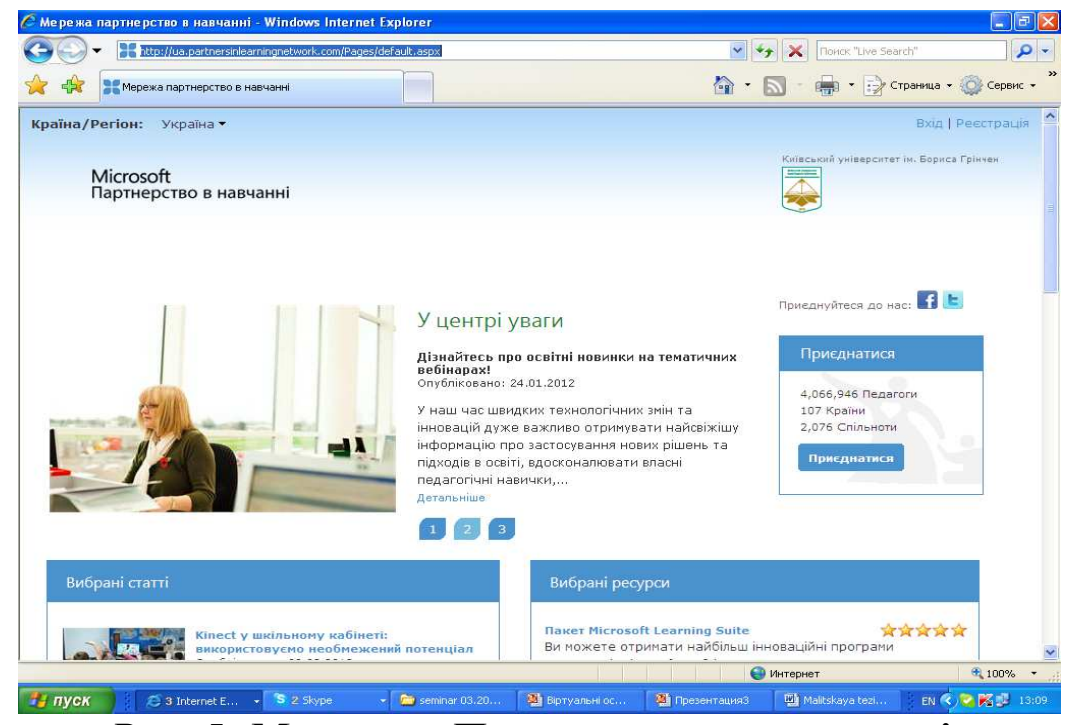

Рис. 5. Мережа «Партнерство в навчанні»

http://ua.partnersinlearningnetwork.com/

Призначення мережі - створювати професійні віртуальні спільноти, спільно працювати над розробкою уроків, навчальних і методичних матеріалів, обмінюватися досвідом й ідеями. Більш спрямована на підвищення якості освітнього процесу іiі можна віднести до віртуальної навчальної спільноти, у якій активно працюють вчителі загальних середніх навчальних закладів, створюючи спільноти вчителівпредметників [19].

Сучасні учні — це діти «цифрового суспільства», які все частіше отримують знання через неформальні засоби, наприклад, мобільні телефони, до яких у будь-який час та у будь-якому місці вони мають доступ. Мобільність, постійний зв'язок через Інтернет й інтерактивність стають одними із складових сучасного навчального процесу.

Висновки. Феномен віртуальних спільнот освітнього напряму вивчається науковцями всього світу. Існують різні підходи щодо визначення термінологічного апарату з цієї проблематики, але до цих пір ще не має єдиного бачення й узгодження дефініцій. Різноманітність підходів ускладнює розуміння цього явища стосовно його використання в навчально-виховному процесі школи. Виникає необхідність упорядкування термінології, а також подальшого дослідження впливу віртуальних освітніх спільнот на результати навчальної діяльності учнів загальної середньої школи. 


\section{Список використаних джерел}

1. Стратегія «Европа 2020» (“Europe 2020” Strategy) [Електронний ресурс]. — Режим доступу: http://ec.europa.eu/europe2020/index_en.htm.

2. Webster's new world dictionary of the American language. College Edition // The world publishing company. - 1959. - $1724 \mathrm{p}$.

3. The Concise Oxford Dictionary of current english. Seventh edition. Edited by J.B. Sykes. Oxford University Press, 1987, 1264 p.

4. Ожегов С. И. Словарь русского языка // С. И. Ожегов / под ред. д. ф. н. профессора Н. Ю. Шведовой. - М. : Изд-во «Советская энциклопедия», 1973. — 846 c.

5. Словарь интернет-терминов [Електронний ресурс]. - Режим доступу : http://internetrabota.net/news/read/dictionary.html].

6. Словник Інтернет-термінів netlingo [Електронний ресурс]. — Режим доступу : http://www.netlingo.com/dictionary/o.php].

7. (Rheingold, 1993,p. 5) (Defining "Virtual Community" Catherine M. Ridings Lehigh University, USA) [Електронний pecypc]. - Режим доступу : http://www.21stcenturycollaborative.com/2007/07/virtual-communities-as-a-canvas-ofeducational-reform/.

8. Англо-український тлумачний словник з обчислювальної техніки, Інтернету $\mathrm{i}$ програмування. — Вид. 2. — К. : Видавничий дім «СофтПрес», 2007. — 824 с.

9. Кудрявиева С. П. Міжнародна інформація : навч. посіб. / С. П. Кудрявцева, В. В. Колос. — К. : Видавничий Дім «Слово», 2005. — 400 с.

10. Портал Європейського Союзу «Elearningeuropa.info» [Електронний ресурс]. — Режим доступу : http://www.elearningeuropa.info/es/article/Etienne-Wenger.

11. Бондаренко C. B. О типизации виртуальных сетевых сообществ образовательной направленности // Новые инфокоммуникационные технологии в социально-гуманитарных науках и образовании: современное состояние, проблемы, перспективы развития / под общ. ред. А. Н. Кулика. - М. : Логос, 2003. - С. 399407.

12. U. Carlen."Typology of Online Learning Communities", presented at First International Conference on NetLearning2002, Ronneby, Sweden, 2002 [Електронний pecypc]. — Режим доступу : http://www.lorenzoguadamuz.net/Docs/pdf. 
13. Литвинова С. Г. Віртуальні предметні спільноти як засіб підтримки природничо-математичної освіти [Електронний ресурс] / С. Г. Литвинова // Інформаційні технології і засоби навчання. — 2012. - № 2(28). - Режим доступу : http://www.nbuv.gov.ua/e-journals/ITZN/2012_2/11midpzd.pdf. — Назва з титул. екрану.

14. SITE (The Society for Information Technology and Teacher Education) Суспільство для інформаційних технологій та освіти вчителів [Електронний ресурс]. - Режим доступу: http://site.aace.org/.

15. iTEC (Innovative Technologies for an Engaging Classroom) Інноваційні технології для удосконалення класної кімнати [Електронний ресурс]. - Режим доступу : http://itec.eun.org/web/guest..

16. iTILT - Interactive Technologies in Language Teaching Інтерактивні технології у навчанні мовам [Електронний ресурс]. — Режим доступу : http://itilt.eu.

17. Міжнародний проект «еTwinning» [Електронний ресурс]. — Режим доступу : http://www.etwinning.net/en/pub/index.htm.

18. Teach.us [Електронний pecypc]. - Режим доступу : http://www.eun.org/web/guest/projects/current.

19. Мережа «Партнерство в навчанні» [Електронний ресурс]. - Режим доступу : http://ua.partnersinlearningnetwork.com.

\section{ФЕНОМЕН ВИРТУАЛЬНЫХ ОБРАЗОВАТЕЛЬНЫХ СООБЩЕСТВ В СИСТЕМАХ ОБРАЗОВАНИЯ ЗАРУБЕЖНЫХ СТРАН: ПОДХОДЫ К ОПРЕДЕЛЕНИЮ ПОНЯТИЙ}

Малицкая Ирина Дмитриевна, старший научный сотрудник Информационноаналитического отдела педагогических инноваций Института информационных технологий и средств обучения НАПН Украины, г. Киев, e-mail: Irina_Malitskaya@mail.ru

\section{Аннотация}

Популярность виртуальных сообществ, которые существуют и постоянно развиваются в сети Интернет, повлекла создание виртуальных сообществ образовательного направления. Их возможности успешно используются в системах образования зарубежных стран, в том числе в учебном процессе общеобразовательной средней школы. Феномен виртуальных образовательных 
сообществ является темой исследования многих современных ученых, согласование терминологического аппарата продолжается и сейчас. В статье проанализированы и предложены некоторые подходы относительно определения понятий по этой проблеме, а именно: виртуальных, виртуальных образовательных и виртуальных учебных сообществ.

Ключевые слова: информационно-коммуникационные технологии, виртуальные образовательные сообщества, виртуальные учебные сообщества, общеобразовательная средняя школа, зарубежный опыт.

\section{THE PHENOMENON OF VIRTUAL EDUCATIONAL COMMUNITIES IN THE SYSTEMS OF EDUCATION OF FOREIGN COUNTRIES : APPROACHES TO DETERMINATION OF CONCEPTS}

Iryna D. Malytska, senior researcher of the Information-analytical department of pedagogical innovations of the Institute of Information Technologies and Learning Tools of the NAPS of Ukraine, Kyiv, e-mail: Irina_malitskaya@mail.ru

\section{Resume}

Popularity of virtual communities which exist and constantly develop in Internet caused a creation of educational virtual communities. Their possibilities are successfully used in the systems of education of foreign countries, including the educational process of secondary school. The phenomenon of virtual educational communities is the theme of research of many modern scientists, the concordance of terminology is under discussion. In the article some approaches to determination of concepts on this issue are analysed as well as offered some definitions, namely: virtual, virtual educational and virtual learning communities.

Keywords: information and communication technologies, virtual educational communities, virtual learning communities, secondary school, foreign experience. 